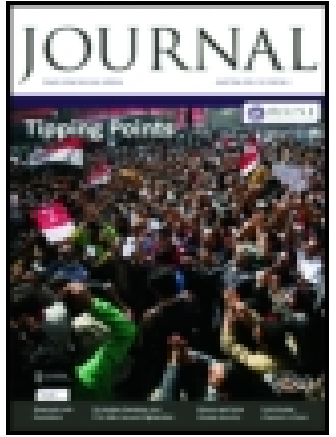

Royal United Services Institution. Journal

\title{
The Importance of Sea Power in the Growth of the Roman Empire, and the Lessons Taught to Great Britain
}

Mr. William W. Marshall B.C.L., M.A., F.R.S.L.

To cite this article: Mr. William W. Marshall B.C.L., M.A., F.R.S.L. (1899) The Importance of Sea Power in the Growth of the Roman Empire, and the Lessons Taught to Great Britain, Royal United Services Institution. Journal, 43:259, 947-967, DOI: 10.1080/03071849909423636

To link to this article: http://dx.doi.org/10.1080/03071849909423636

Published online: 11 Sep 2009.

Submit your article to this journal $₫$

Џll Article views: 11

Q View related articles $\sqsubset$ 


\section{THE JOURNAL OI TFE- \\ ROYAL UNITED SERYICE INSTITUTION.}

Vol. XLIII. SEPTIMBER, $1899 . \quad$ No. 259.

[Authors alone are responsible for the contents of their respective Papers.]

THE IMPORTANCE OF SEA POIVER IN THE GROIVTH OF THE ROMAN EMPIRE, AND THE LESSONS TAUGHT TO GREAT BRITAIN.

By MT. WTLITAM W. MARSHALL, B.C.L., M.A., F.R.S.L.

Friday, 26th May, 1899.

J. K. Laughton, Fsq., R.N., Professor of Modern History, King's College, London, in the Chair.

THE influence of Sea Power upon the history of humanity forms a subject which needs no apology at the present time, and especially before the audience which I have now the honour to address.

The heart of Great Britain has at length been awakened to the necessities and the responsibilities of her position as the foremost nation of the world; at length she realises the importance of her First Line of Defence, the life-belt of buoyant steel guarding her mercantile marine, which is the life-blood of her being; and any light from whatsoever source shed upon the secret, humanly speaking, of her greatness is not without interest to those who are humbly proud of that greatness, and who would maintain it at the cost of their wealth, of their labour, and of their lives.

Nor are the lessons of ancient history without their peculiar value. It might perhaps be asked how we can compare the ancient war-ships, propelled by oars, with the mighty engines of offence and defence which modern science has given to our age of progress. The resemblances are many and important. It is pointed out to us by Captain Mahan, in what may be called an epoch-making work--" The Influence of Sea Power on Hislory" - that the principles of strategy remain much the same, though tactics change with mechanical inventions. The great principle of strategy is to have the right force in the right place at the right time. It is thus that in all ages the greatest battles of mind against mind must ever be fought and the greatest victorics, though sometimes bloodless, must ever be won. Noreover, even as regards tactics, the modern warship resembles those of the ancient Romans much more than it resembles

roL, XLIII, 
the sailing ressels of a century ago in at least one most important point. In the days of sailing ships the fate of battles was borne on the wings of the wind. A head wind placed a fleet at a terrible disadvantage, while a calm rendered the finest vessel afloat little better than a helpless hulk upon the waters. But the Roman galley was as independent of the wind as the modern battle-ship, except in so far as man-power is weaker than steam-power and muscles tire more rapidly than steel. Nor was this the only point of resemblance. One terrible weapon in modern naval warfare is the ram, and this in skilful hands was the most potent weapon of the ancient battle-ship. The complicated manourres, by which the beaks were driven into the weakest spot of the enemy's vessels, were the secret of scientific naval warfare. The Roman warship, moreover, in its various forms was a formidable fighting machine. It was a vessel of considerable length in proportion to its beam, usually fitted with five banks of oars, but frequently: with more. Even the smallest cruisers with a single bank had twenty-five oars a side. The stern was high out of the water, and here the helmsman stecred by means of two long sweeps. The bows were protected with metal plates, and armed with one or more beaks or rams; the earlier form of ram was above the water-line, but an improved type was afterwards introduced with three or four sharp metal points fixed on a level with the keel. At the beginning of the Empire turret-ships were used, ficry missiles and heavy weights being discharged by hand or engine from a great tower on the deck. The ships had an auxiliary mainsail for use on long voyages, but the mast was lowered and all top hamper stowed before going into action. - The crew of an average battle-ship must have numbered at least 250 or 300 men without counting the marines.

The various Commands of the Sea at different pcriods of ancient history are numerous and well defined. We might tell of Minos of Crete and his Sea Power in the thirteenth century before our era; we might tell of Agamemnon of Mycenae and the naval expedition against Troy", immortalised by Homer; and so on down the tide of history for a thousand years from the thalassocracies of Miletus, of Samos, of Corinth, of Corcyra, of Aegina, and other Powers, till we reach the story of Genseric the Vandal in the fifth century of our era when he sailed up the Tiber and pillaged Rome, sank fleet after fleet of the Romans, and ravaged year by year the greater part of the Mediterranean seaboard.

Above all we might look at the Sea Power of Athens. We might tell how at the bidding of the God, as interpreted by Themistocles, the Athenians trusted to their "wooden walls," to their hearts of oak. We might tell how by these "wooden walls" the wave of Asiatic despotism was flung back from the coasts of Greece, and of that great day, when -

"A King sate on the rocky brow

Which looks o'er sea-born Salamis,

And ships by thousands lay below,

And men in nations-all were his!

He counted them at break of day-

And when the sun set, where were they?" 
WVe might tell how, through the wisdom of Pericles, Athens improved her opportunities and won her naval Empire; how the skilful tactics of Phormio and those who learnt his secret gave victory after victory to her arms; and how at last the loss of her Navy in the Great Harbour of Syracuse sealed once and for ever the sentence of her fall.

Why then amidst this wealth of history should Rome be chosen as the centre of thought in the story of naval supremacy in the ancient world?

It is not because the Romans give us more details than other nations of the doughty deeds of their seamen. Of the Romans it was especially true that their naval heroes were a strange race, something apart from themselves, a phenomenon which they did not understand. It is difficult for a people, who love the sea and look upon it as their fricnd in peace and their ally in war, to realise the feelings of the ancients. Just as the Greek philosopher, in spite of the glories of Salamis, could look upon death by drowning as a disgrace, so the Roman writers have no good word for the angry, cruel, restless, faithless sea, with its foaming, sunken reofs, and its huge, swelling, surging, threatening waste of waters. Their hatred of the sea was reflected in their estimate of their sailors, and the Navy was regarded as a less honourable branch than the sister Service. More honour then to their Navies, which helped to win, to consolidate, and to preserve their Empire.

But the reason why Rome is chosen as the test case of Ancient History is that the Empire of Rome was by far the greatest of the civilised Empires of antiquity. It had not only greatness, like the mushroom Empire of Alexander, bint it had also solidity and permanence. And there is another reason. Rome was the typical military Power of the ancient world; and here it is necessary to guard against any misconception. In showing the services of the Roman Navy, nothing should be further from our thoughts than to depreciate the work of her Land Forces. Her Armies were the very breath of her life, the fundamental condition of her existence. And therefore Rome has been chosen to prove the value of Sea Power even to a nation whose stiength was in her soldiers and in the genius of her generals.

The Sea Power of Rome dates from the First Punic War, the commencement of the long struggle between Rome and Carthage; and it is impossible to form a just estimate of the importance of this war without a brief study of the origin of Carthage and of the traditions of the Phoenician race. Carthage was the chief settlement of the greatest commercial and naval Power of antiquily. Phoenicia, her mother country, was in every way fitted by geographical conditions to be the cradle of the maritime enterprise of the world. A narrow strip of land, north of Palestine, between the Mediterranean and the richly timbered heights of Lebanon, it was not only the terminus of the great caravan routes from Arabia, and from India and the Far East, but it presented an extensive coast line in proportion to its size, and its valleys were divided by mountain spurs, which ran out to sea and formed shelter for the many harbours on its river mouths. The chief towns were Sidon and Tyre. "Great Zidon," was 
probably the oldest city of Phoenicia ; but it was eclipsed in power by its colony Tyre, "the daughter of Sidon," which lay 20 miles further south. The Phocnicians were of Semitic origin, and closely akin in race and language to the Hebrews, the Jewish Kingdom forming the hinterland of the Tyrian territory.

The maritime enterprise of the Phoenicians was unprecedented. Not only were they the great carriers of the ancient world, but their colonies were innumerable. It would take more than the whole time at my disposal to give even a brief outline of the estent of their colonisation. We find their settlements on the Arabian Gulf and in Egjpt, on the Black Sea, șcattered over the whole of the Mediterranean, and out beyond the Pillars of Hercules, southward on the West Coast of $A$ frica, and northward in Spain, in Cornwall and the Scilly Isles, and in Jutland.

But we must especiaily notice the great chain of colonies commanding the narrow seas off Sicily, and forming a sort of Gibraltar, which effectually shut their rivals, the Greeks, from the Western MIediterrancan. Here they had naval stations or factories at Malta, Thapsus, the Lesser Leptis, Utica, Hippo, and Carthage; across the water the Aegatian Isles, Agrigentum, Lilybaeum or Marsala, Drepanum, Eryx, Panormus or Palermo, and the Liparae Islands.

Great was the maritime enterprise of the Phoenician race; but they made two fatal blunders, which may teach us a double lesson. In the first place, the spirit of the race was wholly commercial; they neglected their Navy; and hence they were conquered again and again. The Athenians hated trade; they fell and lost their Empire. The Phoenicians fell, because they loved trade and trade alone. The Romans combined commercial enterprise with Imperial policy, and their Empire lasted century after century till the soul of the nation was dead. In the second place, the Phoenicians failed through that want of combination and power of union, which is characteristic of the Semitic races. Had Tyre and Sidon united with Carthage and their other colonies, there is little doubt that the Phoenician race might have been supreme to-day. But there was jealous rivalry between the mother cities and the daughter States, and that rivalry spelt ruin. Imperial Federation in the Phoenician Empire would have changed the history of the world.

It was when the Eternal City came into collision with Carthage, Queen of Phoenician colonies, that she first realised her need of a Navy. Her ambition was no longer limited to the narrow confines of Italy, and the one great obstacle to her schemes of colonisation and conquest was the Sea Power of Carthage. Before Rome could found an Extra-Italian Empire she must first meet the Navies of the chief maritime Power of antiquity. In 204 B.c. an opportunity offered which Rome was not slow to embrace. The port of Messana, the key to Sicily, was in the hands of some Italian pirates, known as Mamertines. The Greek town of Syracuse and Carthage, in the interests of her Sicilian commerce, determined to sweep these rovers from the seas. The pirates appealed to Rome, but-so weak was Rome's Naval Power that the Carthaginian Adniral boasted that he would not suffer them so much as to wash their hands in the waters of the Straits. 
The First Punic War began. With great difficulty the Roman troops were thrown across into Sicily, and the war was prosecuted with such vigour that Syracuse joined the Roman cause. But at every turn the Romans were crippled by the enemy's fleets, and a notable instance of this is seen at the siege of Agrigentum, where the Carthaginians were cnabled to cut off supplies and reduced the besieging force to a condition of impending starvation.

At this crisis there appeared upon the scene a man to whom is due the proud title of Father of the Roman Navy-Duilius, a Plebeian Consul. His foresight showed him that Sea Power must be met by Sea Power, and the Roman Government realised that nothing could be effected with the few vessels of an obsolete class which formed their only claim to maritime strength. At such a low ebb was Rome's knowledge of naval affairs that Duilius had to wait till a Carthaginian vessel was wrecked on the southern coast of Italy before he could secure a model of the then modern type of war-ship. But aftcr once obtaining his model he lost no time. In sixty days by unparalleled exertions a fleet of 120 sail was built and launched.

But Duilius not only saw the need of a flect, but realised also the inferiority of the material with which he had to man that fleet. It was idle to expect that his hastily trained crews of Italians could cope with the Thoenician seamen in scientific tactics and mancuvres. To remedy this, heavy gangways about 36 feet long were placed erect in the bows of the battle-ships. The Romans closed with the enemy and laid their ships alongside. Then the gangways were let fall, and the spikes underneath piercing the enemy's decks lashed the vessels together. It became an affair of boarders, and the Romans could fight hand-to-hand with a bull-dog courage known only to them and to Britons.

There follows now one of the most remarkable chapters in the history of the world. The Romans were landsmen pure and simple; their opponents were the finest sailors of antiquity. Through stress of weather the Romans lost fleet after fleet, but with the exception of one reverse they won every engagement at sea of any importance throughout the war. The whole story is summed up by Horace in a line-" The Sicilian Sea crimson with Carthaginian blood."

In 260 n.c., Duilius, with his new fleet, met the enemy off Mlylae in the north-cast of Sicily, and won a brilliant victory, sinking 14 and capturing 31 of the Phoenician vessels. So he laid the foundations of Rome's Sea Power and of her Empire. The Columna Rostrata was erected in the Forum, decked with the beaks of the captured war-ships, and we can hardly avoid a smile as we read of the simple honours paid to the first great Roman Admiral by the decree that he should be escorted home from banquets at night by a procession of fute-players and torch-bearers.

Four years after the battle of Mylae, Regulus won another great victory for Rome off Ecnomus on the south-west ccast of the island, the Carthaginians losing over 100 war-ships. In this battle it is said that no less than 700 ships and 300,000 men were engaged. Regulus sailed on to Africa and landed his troops; but they were defeated and he 
was captured; and it was only the superiority of the Roman flect which enabled it after a sharp brush with the enemy to embark the remnant of the army and sail for Rome. But the Romans were now to meet with a foe mighticr than they. A great galc arose, which dashed upon the Sicilian shore their first war-flect, and strewed with the bodies of men and the wreckage of 270 ships the whole coast from Camarina to Pachynus. With indomitable perseverance within three months the Romans had a second flect of 220 vessels ready, and with this they scized Panormus, the modern Palermo, one of the most important naval stations of the island. But in the following year this flect too was shattered by a gale, and Rome for the moment was disheartened. She gave up the Command of the Sea, with the result that the Carthaginians made a vigorous, though unsuccessful, attempt to retake Palermo, and there followed the greatest land battle of the war.

Then the Romans again took heart, and built a third feet of 200 battle-ships. The reply of Carthage is worthy of note. It was a proposal for peace. Peace was refused through the patriotic derotion of Regulus, and the fleet was sent to invest Lilybaeum or Marsala, the strongest of the Carthaginian fortresses. But the Roman commander lost most of his ships in an attempt to surprise the Carthaginian flect in the neighbouring harbour of Drepanum, and the remainder of Rome's third fleet was lost on the fatal coast near Camarina with its convoy of 800 merchant-vessels carrying supplies to the troops on the western coast. Again the Romans gave up the sea, and the chance thus offered was seized by Hamilcar Barca, the father of Hannibal. He established himself in the north-west corner of Sicily, and ravaged even the Italian seaboard, while plentiful supplies were brought by sea to the beleaguered stronghold of Lilybacum.

Once more the Romans realised that Sea Power was vital to their existence. But the trcasury was empty, and it was only with funds raised by the wealthier citizens in a spirit of glorious patriotism that a fourth flect was equipped for sea, and despatched under Catulus to blockade Drepanum. That fatal sense of security, which sometimes steals over a nation, had caused the Carthaginian Government to neglect their Naval Power; but a considerable fleet was hurriedly collected and sent to raise the blockade. It was met by the Romans off the Aegatian Islands, and 50 battle-ships of Carthage were sunk and 70 captured. This great naval victory in the spring of 241 B.c. ended the First Punic War. The terms of peace included no demand for the surrender of the Phoenician flect. It was already practically annihilated. Rome was now Mristress of the Mediterrancan, and Sicily, the granary of Central Europe, became Rome's earliest Province, the first-fruits of her Empire.

Betwcen the First and Second Punic Wars certain minor events occurred of importance to our subject.

The Inexpiable War-a war without quarter and without mercy-broke out between Carthage and her foreign mercenaries. The great Phoenician Power, which the might of Rome herself had been able merely to cripple, was in danger of losing her rery existence through the foreigners 
employed in her service. And here is a warning to our own Mercantile Marine. If it is a sound and wholesome law that a British ship must be owned by British subjects, should sle not be manned by British subjects ? Our Mercantile Marine should be a training school for our Navy in the hour of need. Should the patriotism of our shipowners allow the finest mercantile service the world has ever seen to be a school for foreign seamen, a reserve it may be for the Navies of Britain's foes?

At the close of this Inexpinble Wiar, Rome demanded the cession of Sardinia and Corsica. It was owing to the Sea. Power of the Romans that Carthage dared not refuse, and these islands became Rome's second Province. Then in 229 n.c., the Romans sailing from Brindisi with a powerful fleet beat Tcuta, the pirate queen of Illyricum, on the cast of the Adriatic, an ideal haunt for rovers of the sea. The Illyrians were ordered not to appear south of Lissus with more than two ressels at a time, and Illyricum became a Roman Protectorate. 'Ten years later Rome crushed the successor of Teuta, Demetrius the Traitor, who intended to assist Hannibal, and they kept possession of threc important strategic positions : Corcyra, Dyrrhachium, and Apollonia.

We now come to what is usually regarded as the most purcly military episode in the history of this great military Power-the Second Punic War, or the Campaigns of Hannibal.

It is a matter of regret that it would be impossible in the whole of this hour to touch, in more than the most cursory manner, upon the greatest war of antiquity. It is a matter of less regret, because the subject has already been sketched with a light but masterly hand by the author of "The Influence of Sea Power on History." But there is no war in any country or in any age where the side-lights of history will teach us more useful lessons.

The story of the campaigns runs usually as follows. After the siege of Saguntum, war was declared, and in the spring of 218 B.c. Hannibal set out from Carthago Nova, in Spain, to march into Italy. He crossed the Pyrenees, the Rhone, and the Alps, probably by the Pass of the Little St. Bernard, defeated the Romans at the Ticinus and the Trebia, tributaries of the Po; crossed the Apennincs, and beat Flaminius at Lake Trasimene in 217 в.c.; was baffed for a while by Fabius Maximus, the Delayer; crushed the Romans in 216. B.c., at Cannac, and might perhaps have taken Rome; lost his brother Hasdrubal, and the reinforcements from Spain in 207 s.c., at the River Metaurus; and after holding out in Italy for five more years was beaten by Scipio Africanus, on the River Bagradas, near Zama in Africa.

But the central point of interest is the "splendid isolation" of Hannibal. We are told that this was due to the jealous lethargy of the Carthaginian Government; but the side-lights of the story show that it was chiefly due to the Sea Power of Rome.

The first step in the war was that the Roman Consuls were ordered to raise such land forces as seemed desirablc, and "as large a fleet as they could." Again, Livy tells us that the Romans did not think the Carthaginians would dare to invade by sea, such was the strength of 
Rome's Navy, while the Carthaginians expected the Romans would prosecute the war with that branch of the Service in which they had proved success. ful in the previous struggle. To meet the emergency, an extraordinary tax of "ship-money" was levied upon the citizens of Rome.

Time will not permit us to go into details. But it was the Roman fleet in the Gulf of Ljons which compelled Hannibal to take the perilous route across the mountains, which carried Scipio back to Italy to mect him there, and which threw an army into the north of Spain to stop his brother Hasdrttbal from bringing reinforcements. It is trute that we find solitary instances of Carthaginian successes at sea. We hear, for example, of a convoy of merchantmen with supplies for the Roman forces in Spain being intercepted by the enemy; of Bomilcar landing in the south of Italy; and of Mago joining the Gauls near Genoa. 3ut the fact that there was no great naval battle proves the acknowledged superiority of Rome at sea, and Hannibal's isolation and the cause of his failure may be seen by a glance at the seat of war.

Hannibal had three bases: Carthago Nova in Spain, Carthage in Africa, and the allied State of Macedonia.

If we draw a line from the Roman naval base in Spain at Tarragona, past the southern extremity of Sardinia, to Lilybaeum or Marsala in Sicily, and another from Syracuse on the east coast of the island to the shores of Epirus, it can be shown that the Mediterranean north of these lines was during most of the war indisputably commanded by Rome. The line of communication from Spain was broken by 'larragona and the army at the foot of the Pyrenees, the Romans even seizing Carthago Nova itself; that from Carthage by the fleets at Marsala, Palermo, and Messina; and that from Macelon by a powerful squadron at Brindisi.

Hence resulted the isolation of Hannibal, and the erer glorious but hopeless struggle of a single man against a nation.

It has been a matter of surprise how, in face of the Roman supremacy at sea, Hannibal was able to cross over to Africa at the close of the war. In 203 B.C., Scipio then in Africa, at the request of the Carthaginian Government laid down certain terms of peace, sufficiently harsh and including the withdrawal of their armies from Italy and Gaul. The Carthaginians accepted the terms, and Livy-a far shrewder historian than is commonly supposed-gives the reason very distinctly; it was simply to gain time till Hannibal could cross into Africa. An armistice was concluded, while enroys were sent to Rome. The two brothers in Italy and Gaul, Hannibal and Mago, were recalled. 'The latter died on the passage, and some of his ships were captured by a Roman admiral, who had probably not yet heard of the armistice. But Scipio was bound by its terms, and -especially as Hannibal was fulfilling by his withdrawal one of the conditions of the proposed peace-he could offer no opposition to his return to Africa.

After Hannibal's final defeat at Zama, it is a significant fact that the terms of peace included the surrender of all Carthaginian war-ships except ten cruisers. 
The next great Power with which Rome came into collision was Macedonia. We have seen that Philip. of Macedon made an alliance with Ilannibal, but owing to Rome's power at sea could do nothing to help him in Italy. He prepared a large naval force, and took Oricum and besieged Apollonia as bases for an invasion of Italian soil. But the Romans blockaded the mouth of the Aous with their flect, and Philip was forced to burn his ships and retire from the sea. Through the whole story we see how, as Mommscn says, "the want of a war-flect paralysed Philip in all his movements." He could take no offensive measures against Italy, and Rome could throw an army at her pleasure into Epirus. Then the Roman Senate commissioned for service in Greece a small squadron, which seized Aegina and proved sufficient to hold Philip in check. In 201 n.c. he crossed into Caria, but fleets of Roman allies blockaded him so closely that he with difficulty returned to Europe, and Roman fleets sailed again for Greece and the stronghold of Chalcis in Euboea was taken. I'hilip was most vulnerable in Thessaly, but there the Roman armies were strongly supported by their Navy, while the seaport of Anticyra in Phocis became also a base of operations. A Roman fleet then moved on Corinth and shook the resolution of the Achaean Leaguc, so that they withdrew from alliance with Macedon. The final battle was fought on land at $C$ ynoscephalae in Thessaly, but that battle could never have been fought and won without the co-operation of the fleet; and the Romans showed that they realised what the sea meant to Macedon by making peace only on condition that all the Macedonian vessels were surrendered to Rome.

Next in order in 190 B.c. there follows the great Syrian War with Antiochus the Great, whose dreams of conquest reached East and West far beyond the bounds of possibility. 'This too was ended by a land battle, but the course of the war was shaped long before by the fleets of Rome. After Zama, Hannibal had taken refuge at the Syrian Court, and when Rome demanded that Antiochus should restore to Macedon the Thracian Chersonesc, Hannibal advised him in the strongest terms to act on the offensive, and either to let him invade Italy with Carthaginian troops or to strike the blow himself. It was Rome's Navy which made him unable to follow this sound advice. Greece he did invade, but the Romans beat him and they beat his fleet, and he had to fall back on Asia Minor, while Naupactus or Lepanto-the chief naval station of his Aetolian allies-fell into the hands of the Romans. Before the decisive struggle Hannibal tried to help him by bringing up Phoenician mercenaries, but some Rhodian war-ships were told off to patrol the coast and intercept him, and the gallant islanders with a Roman squadron met the fleet of transports off Myonnesus, north of the Gull of Ephesus, and sank or captured more than half the enemy. Not only did this engagement deprive Antiochus of his reinforcements, but its results were much more far-reaching. 'The Syrian ling was so disheartened that he withdrew his forces from the Hellespont and left the passagc open to the Roman troops. Scipio landed without opposition on the Asiatic shore; moved southwards, and defeated Antiochus near Magnesia, when the Romans lost 400 men and the Syrians 
53,000: Once more, as with Macedon, when the war was ended, the terms of peace forced the Syrian monarch to give up for ever his entire fleet of war-ships.

Next we come to the last Mracedonian War, which gave to Rome the final victory over the successors of Alexander the Great. In 171 B.c., war was declared against Perscus, son of Philip, and Rome's Navy enabled Crassus to throw a full consular army into Eipirus. Perseus must have despaired of success at sea, when he gave orders for the destruction of his arsenal at Thessalonica, but on both sides the war was desultory for a time. At length, in 168 B.c., the Romans determined to dally no longer. Octavius took command of the flect, and Aemilius Paulus hastily crossed from Brindisi to Corcyra. Historians give us little detail of the naval engagements in this war, but Cicero with his usual sagacity, tells us that the Romans conquered Perseus with their flect. It is incredible that a statesman like Cicero should have made such an assertion of a time not more remote than the American War of Independence is from our own day, unless it had a very real foundation in truth. The final battle, which broke for ever the power of MIacedon, was fought on the plains of Pydna, but we cannot doubt that the way for that victory was paved by the flects of Rome. King Perseus fled, and Octavius with his fleet ever on the watch pursued him to Samothrace, and forced him to surrender. The terms of settlement forbade the Macedonians even to cut timber for ship-building.

Then came the Third Punic War, after fifty years of peace between Rome and Carthage. Commercial jealousy ran high, and Rome could not brook a great mercantile Power within three days' sail of the Tiber. Cato's dictum that "Carthage must be destroyed" became the watchword of Rome's policy. A pretext was soon found, and after the surrender of 300 noble youths as hostages, and all her arms and engines. of war, Rome's ultimatum went forth that Carthage must be pulled down, and might be re-built ten miles from the sea. The Carthaginians were not slow to realise that this meant death at once to commercial prosperity, to maritime supremacy, and to imperial power. They resolved to resist to the end. - The temples were turned into workshops, and the women gave their long hair for bowstrings. But their Naval Power was gone, and with it all hope of victory. Carthage had to dic, but she died game and she died hard. Rome's flects harassed her on all sides. At last the younger Scipio blockaded the port, and-to prevent blockade-runningthrew a mole across the harbour mouth, ruining it then and for all time. Then the Carthaginians built a squadron of 50 vessels, cut a new exit from the harbour, and gallantly attacked the besieging fleet. But their bravery was of no avail, and Carthage fell. The city was defended street by street, house by house, and storey by storey. But fire completed the work which the sword began, and out of 700,000 souls at the commencement of the siege, only 50,000 at length surrendered to the Romans.

In the same year, 146 n.c., another great maritime Power fell before Rome's war-ships. Fair Corinth-the Paris of the ancient world, and one of its chief commercial centres-was the scene of the last stand of the 
Achacan League. Metellus had marched from Macedonia, and was in sight of the city, when MIunmius the Consul landed from his ships on the isthmus, and took over the command. Corinth fell, and Mummius has been held up to the ridicule of ages for contracting with the shipowners, who were to carry the priceless art treasures of the city to Rome, that if they lost them they were to replace them with others of equal value. Possibly this ridicule is ill-founded. It seems probable that, under the complicated laws of bottomry which we know existed in Greece, MIummius, on the advice of his Greek friends, merely made one of the many forms of contract for marine insurance then common in Greek commerce, and that his action shows that he valued these works of art rather than that he underrated their worth. Be that as it may, the art treasures of Corinth were carried to Rome to spread the light of Greece for all ages through countries, like our own, still wrapped in the gloom of barbaric darkness. Thus ended the Achaean League, and one more Province was added to Rome's Empire.

Next we come to a remarkable and most interesting failure through want of Sea Power, interesting because it concerned our own brothers by blood. About the beginning of the first century before our era, there were four sister tribes in the Cimbric Chersonese, corresponding roughly to Schleswig-Holstein. Two of these, the Cimbri and the Teutones, 300,000 fighting men with their families and servants, set out by land to find new homes. They swept over a Roman host at Arausio, the modern Orange, and left 120,000 of the encmy dead upon the field. But they were not only routed, but annihilated by Marius at Aquac Sextiae and near Vercellac on the Raudine Plains. The other two sister tribes, the Angli and the Saxones, some centuries later, took to the sea-and they are ourselves, the Anglo-Saxons of to-day.

The same lessons of the importance of Sea Power are repeated in the long and intricate course of the wars wilh Mithridates, the rival of Rome for the Iimpire of the East. After the massacre of 80,000 Italians in Asia Minor, it was his fleet which cnabled him to.scize Delos, the chief emporium of Rome in the Acgean, and which induced Athens with her great harbour of the Piracus to join him. Sulla saw that nothing could be done while . Mithridates had command of the sea, and he collected ships from Syria, Rhodes, and Egypt. The Piraeus was surrendered, and the dockyards and arsenals were burnt. In the following year the Mithridatic flect suffered a crushing defeat off Tenedos, Rome was again mistress of the seas, the passage of the Hellespont was open to Sulla's troops, and Mithridates was glad to make terms, even though they included the surrender of his fleet of 70 battle-ships. Through the succeeding wars we can trace again and again the importance of Naval Power. At length Pompey was entrusted with a magnificent flect of 500 sail and 120,000 men to sweep the Cilician pirates from the seas. Yictorious everywhere, he was at once appointed Dictator of the East, and then at last the power of Mithridates was broken, and Rome's supremacy was established in the Eastern world. 
But the conqueror of the East was soon to meet one mightier than he. Cassar, "the foremost man in all the world" soldier, statesman, legislator, scientist, and writer, was soon to be matched in a struggle for Empirc with Pompey his sometime son-in-law. We cannot doubt that Casar had learned well the lessons of his own and former ages, and the importance of maritime supremacy had been bornc afresh upon his mind during his campaigns in Gaul. Their Sea Power had given to the Veneti of Brittany an influence far bejond their actual importance as a State, and he took early measures to meet and crush them on thcir own element. It was doubtless want of opportunity, not want of purpose, which made him at first in the final death struggle inferior at sea to his great rival. But if he could not have Sea Power himself, the next best thing was to neutralise the effect of the Sea Power of his antagonist.

Cresar had crossed the Rubicon. He had defeated the Pompeians in Spain. Pompey himself was entrenched near Dyrrhachium, the Calais of Greece, while his fleet patrolled the coast from its headquarters at Corcyra. With much difficulty and danger Cassar and then Antony succeeded in crossing the Adriatic, and in the spring of 48 b.c. drew lines of investment round Pompey. But the lines were broken, and Casar determined to shift the scene of conflict further East and away from the sea. We can hardly doubt that the chief motive of this strategical movement was to remove Pompey from his naval base. Cxear himself tells us of Pompey's unwillingness to leave the sea and the neighbourhood of Dyrrhachium, where he had collected all his stores and arms, and where provisions for the troops were easily conveyed by his ships, and we learn from Cicero that Pompey's opinion was that "he who holds the sea is master of the world." After Pompey had followed him into Thessaly, Cresar attempted to-break the enemy's line of communications. Pompey decided to risk a decisive battle on the Pharsalian Plains. His forces were shattered, the greater part of the troops submitted to the clemency of Cæsar, and the defeated chief fled to Egypt. Many of his old veterans were in Pelusium, and if Pompey had arrived with a squadron of any strength he might still have become master of Egypt, and so of the world. But he had taken only a few vessels in his hurried flight, and the jealous fears of the Egyptian Government caused him to be murdered on reaching the shore.

Casar followed to Egypt and paid due honours to his rival's memory. He was blockaded by the Egyptians at Alexandria, and cut off from the island of Pharos and the sea. But he realised to the full the importance of restoring communication, and at last effected his purpose by a desperate struggle in which he had to swin for his life. Next year followed the pursuit of the Pompeians. Many of Pompey's ships had gone over to Cæsar, but a considcrable fleet rallied at Corcyra and crossed to Cyrenc in Africa. Cxsar sailed from Lilybaeum in Sicily, landed with his troops, and in the early spring of 46 B.c. won the battle of Thapsus. The remnant of the Pompeians sailed to Spain. Cresar was apparently now too strong for them to risk a naval engagement, and the decisive struggle took place on land at Munda, where the Pompeians were utterly routed. 
Nor was this the end of the story. Pompey's younger son, who had escaped from Munda, realised the value of Sea Power, and turned it to great though ill account. By a strange irony of fate, the son of the very man who had swept the rovers from the Mediterranean collected a great flect of piratical craft, and became master of the seas. He scized Sicily, and stopped the corn-ships coming from Egypt and the Eastern Provinces. A famine ensued at Rome, and he forced the Government to come to terms. Sicily, Sardinia, and Corsica were given to him; but he again gave trouble, and it was not till all the dockyards of Rome had been strained to the utmost, till the great Admiral Agrippa had made the Julian Harbour, and till even slaves were set free to man the thwarts of the battle-ships, that Sextus Pompey was defeated and crushed off Naulochus on the Sicilian coast.

And now we come to an instance where a cause was lost largely through not using the advantage given by a superior naval force. The pilot of the Ship of State was gone, when she most needed his strong hand at the helm. Cassar was dead, butchered by men whom he had pardoned and loaded with honours; and this blundering crime-was destined to redden with blood the lands and waters of the world for half another generation. In 42 B.c. the Republican forces under Brutus and Cassius, the conspirators, had crossed from Asia Minor into Macedonia. They were met near Philippi by the army of the Crsarians. For their supplies both sides were dependent on the sea. The Republican fleet was powerful enough to cut off reinforcements and supplies from their opponents, and the Cxsarians were reduced to despernte straits. They were practically blockaded, and a few days' delay might have resulted in a bloodless victory for the Republicans. But the troops of the latter were ill-disciplined and would not wait till time and hunger did their work. Two battles were fought at Philippi; and both were lost, and with Cassius and Brutus died the last hope of Republican Rome.

Eleven years had passed, and there came one of lecisive battles of the world, a sea fight, the battle of Actium :-

"Through cloudless skies, in silvery sheen,

Full beans the moon on Actium's coast ;

And on those waves, for Egypt's Queen,

The ancient world was won and lost.".

The Republic was already dead, but the issue was not only whether Octavian or Antony and Cleopatra were to win the Empire, but whether West or East was to be supreme in the world. Centuries before the question had been decided at Salamis ; centuries later it was to be settled at Lepanto; now the issuc was tried at Actium; and some day perhaps the question will be re-opened, and the same Grecian waters will again be crimson with the blood of East and West.

War was declared against Cleopatra and virtually against Antony. The latter collected his ships and sailed to Corcyra, intending to act on the offensive. But Octavian was on the alert, his fleet patrolled the coast of Epirus, and Antony withdrew to Patrae on the Gulf of Corinth. 
Agrippa, Octavian's admiral, stationed a flying squadron at Methone in NIessenia to break the enemy's line of communications, and seized Corcyra while Antony's flect was moored inside the Ambracian Gulf, supported by his army on the Actian promontory. Octavian crossed the Adriatic, and established his land forces on the north of the gulf, and Antony-under the influence, it is said, of Cleopatra-determined to abandon his army and sail for Egypt.

The great sea-fight ensued, and we may note certain resemblances between this historic struggle and the defeal of the Spanish Armada. In both the elements played a large part in the contest. In both the conquered were borne in vessels which towered above their pigmy assailants. In both the victors sailed in light, almost piratical craft, well fitted for skilful manouvring against their unwieldy foes. Antony and Cleopatra fled, and before nightfall the Eastern fleet with its vast treasure was sunk, burnt, or captured. Octavian pursued the fugitives at his leisure, but it was only when Antony learned that the Egyptian squadron had joined the conqueror that his heart and his hope failed him:-

"All is lost;

This foul Egyptian hath betrayed me;

My flect have yiclded to the foe."

Antony and Cleopatra met their fate, and Oçtavian became sole master of the Roman world.

From the ruins of the Republic arose the Imperial Dynasty, and the Emperors took measures to preserve by their Navies what the Navies of former times had helped to win; and it is interesting to note what the Romans considered the chicf naval stations of strategic importance in the ancient world. The three Mediterranean squadrons were stationed at Ravenna on the Adriatic, at Nisenum near the Bay of Naples, and at Forum Julium or Frejus in Gaul; while detachments guarded the entrances to the great waterways of the Rhine, the Danube, the Euphrates, and the Nile.

How far the Romans as a nation realised what they owed to their Sea Power, we have few data to show. But it is a significant fact that the Rostra or platform, from which the orators addressed the people and fanned the flame of patriotism in the nation's heart, was decorated-as its name implies-not with the trophies of military victorics or the spoils of vanquished armies, but simply and solely with the beaks of war-ships wrested from her early enemies by the might of Rome. Those grim and silent witnesses, towering above the crowd, proclaimed more eloquently than the tongue of man the one great fact that on the sea Rome's Empire must be won and on the sea that Empire must be maintained.

Nor was the voice of man wanting to confirm their testimony, for Cicero himself, at a time when Rome had for the moment lost command of the sea, bore witness to the same great truth:- "Rome has lost," said he, "much, nay most, of her commercial prosperity, of her honour, and of her Pmperial power; we could once not only protect our own country, but give security to all our allies in the most distant shores by the magic 
of our name; but now we are cut off not only from our colonies, from our own seaboard, and from our very harbours, but even from the main highway of Italy; and yet our magistrates are not ashamed to mount this platform, bequeathed by your ancestors, adorned with naval trophics and the spoils of hostile fleets." These were words worthy of one of the shrewdest statesmen of that or any age, and they found a distant but fitting echo in those of our own Sir Walter Raleigh:- "He who commands the sea controls trade and commerce; he who controls trade and commerce comnands the wealth and riches of the world; and he who controls wealth controls the world."

In conclusion, we might notice a remarkable coincidence and parallel between the history of Rome and that of our own country.

In five centuries, from the foundation of the city to the First Punic War, Rome without Sea Power had not gained a single possession outside Italy, and not even the northern portion of the country now bearing that name.

In three centuries, from that war and from the rise of her Navy, she gained practically the whole of the then known world.

In five centuries, from the Norman Conquest to the Defeat of the Spanish Armada, we gained no external possession beyond a few settlements, more or less precarious, on the East Coast of North America.

In three centuries, with our Sea Power-though we once neglected it, and lost, and deservedly lost, our American Colonies-we have gained, largely during the reign of Her present Gracious Majesty, what we see to-day on the map of the British Empire. The British possessions are usually coloured Royal Red. It would perhaps be more fitting if they were coloured Royal Blue. Then they would include our chi sf possession, the waters of the world, the true "Greatest Britain," so !ong as we retain our supremacy at sea.

Such are a few of the lessons to be learnt from a brief study of the imporfance of Sea Power in the growth of the Roman Empire. And there are no peoples who have more cause or more right than ourselves to lay these lessons to heart. We have every condition of success for a great naval and maritime Power, both in geographical.conditions and in the magnitude and character of our population. We have, moreover, under the most constitutional MIonarch that ever sat upon a throne, a Government of Freedom-free from the tyranny of a Despotism, and free from the greater tyranny of Liberty, Equality, and Fraternity-a constitution-

"Where Freedom broadens slowly down

From precedent to precedent,"

where the life of the people and the thought of the people are as free as the air which they breathe or the wave which they rule.

All this is a heritage, a.great heritage, such as before has been bequeathed to none, and it is ours to hand down to posterity, that they too may enjoy and may guard the glories of our Sea Power and of our Empire, till-

"The war-drums throb no longer and the battle-flags are furled In the Parliament of Man, the Federation of the World," 
Vice-Admiral P. H. Colomb:-I came up from a distance to hear this paper read as a matter of duty. I am going back with the consciousness that my sense of duty has been thoroughly rewarded, because I have enjoyed the paper I have heard as much as any that $I$ have listened to in this theatre. I think it is not only that the paper shows us very decply the nafurc of cause and effect, but it has cvidently been very carefully prepared, and I an quite sure we all feel that it has been most admirably delivered. It is not always that the lecturer can put his pointer exactly" on the spot where he means to put it while he is in the course of reading the paper that is before him, but it is a great matter, following a closely reasoned paper of - this kind, to be able to have your eye directed exactly to the point where it ought to be directed at that particular moment. I think, after all is said and done, that it is an excellent sign of the times that we should have a paper of this kind read in the theatre, because if you look back to our great ancestors who first recognised the importance of the Navy, you find they were always going back to classic times for illustrations of what ought to be done in their own times; and I am bound to think that the lecturer shows us that the illustrations are as pertinent now as ever they were, and that we cannot do very wrong in studying them and carrying them out as time goes on. The man who has done most for our Navy in our own time, Captain Mahan, was the first to take up this particular line, and I think the lecturer does justice to him in drawing attention to that fact. One has alkays understood that the Romans and the Greeks exceedingly despised their seamen, but I suspect one of the chief reasons was because the wharves and the docks, and the repairing places for the ships, were just as grubby in the old times as they are now, and $I$ am quite sure that if we were to draw our inspiration of what our Navy and our commerce is from our docks, and the longshore places, we should despise them just as much. Happily we do not; we go a little further. Although the lecturer is very wise in pointing out that it is easy to make a mistake in the matter of your policies, ancient history slows that if you go for commerce alone you may make yourselves very comfortable and very rich, only to have a terrible collapse at the end; whereas, on the other side, if you go entirely for militarism, so to call it, you will equally come to grief, because, although you will get your power, you will not be able to sustain it. But it is the combination which 1 think we have got at the present time in this country, the combination between commerce on the one side and the military power to sustain the commerce on the other side, that is the right policy to adopt. And then too, we are told, and told very clearly and plainly, how the opponents of Rome failed for want of combination-how it was that the sea Powers did not help one another when they ought to have done so; and if there is anything in the present feeling, if there is real truth in the drawing together of the United States, now growing into a great sea Power, and the British Empire, we can hope that there will be such an alliance between us as will prescrve the sea between us and keep the peace of the world. There is a great deal to be said for this paper. It is full of points from beginning to end, but I should long exceed my limit of time if I were to attempt to go into them. I was struck with the fact-I did not know it before-of how Rome gained her first provinces over sea. I had been always accustomed to think it was rather the other way. When you come to look at the campaign of Hannibal, which Captain Mahan has touched upon, and you begin to see, looking at those black lines on the map, and looking at the place where Hannibal landed, driven there because it was a short sea voyage-with that terrific long line of communications behind him-you can only say:- "Why, what the devil made him go there! Surely to goodness if he was going to conquer the Roman States, there was only one way to go about it, and that was the straight way from Carthage to the Tiber?" But unfortunately there was such a thing in the way as the Roman Fleet, which drove him into Spain and enabled the Komans afterwards to cut his communications in Spain and reduce him to the position of a flying column, which we all know has ultimately to disappear in some way or other. We must recollect in all these questions that we 
tre not dealing with naval war here. Natval war is of a different character. This was military war carried across the water in ccrtain cases, and the Romans were wise enough to understancl that if they did not keep the road clear they could not get along it. But their power and the immense advantages they gained were brought about by their perfect understanding of that very simple point, which was a point which the Carthaginians seemed to have altogether lost sight of; it was no good their preparing a great army, unless the roads for the movenent of that army were kept perfectly clear. It was very pretty, I think, the way the lecturer drew our attention to the delivery of the orations from the rostrum in Rome, and how that great military nation did not adorn that rostrum with military trophies, but with the beaks of the ships that they captured from their enemy. But the lecturer has also shown us how readily opinion changes. We do not know how, and we do 'not know why-how one nation with everything apparently plain before it, takes the wrong line, develops the wrong force, and comes to grief over it. So that we have Cicero talking of the rostrum and its meaning, almost exactly in the same way as Pepys talked so many centuries later in saying:- "And we are now fortifying ourselves and yet we are not ashamed."

Vice-Admiral Sir Nathaviel. Bownen-SMitu, K.C.B.;-The lecture which we have just heard hardly admits of any discussion, although it will be a great addition to our Jotisis. It is an interesting historical sketch of the effect of sea power, and the lecturer has, I think, done justice to his subject. He gave us an amusing aneedote as to how one of the first Roman atdmirals who gained a victory was rewarded by being escorted home after his banquets bylutte-players and torch-beirers. I think we ought to be glad that this gallant old warrior had not to be carried home on it shutter, after some of those libations. he probably took part in. As the lecturer points out, before the first Punic War Rome was not powerful at sea, although the Mediterranean wris for the ancient world the great highway of commerce. The supremacy of Carthage at sea was absolute at that period, her transports and war galleys were seen at many Mediterranean ports, and had she maintained her naval supremacy Hantibal need not have lost more than half his army by crossing the Alps. Rome, however, was already creating a Nary and realising the importance of sen power. She eventually conquered her great rival on her own element. This has been all so well told by the lecturer and has been so fully dealt with by that prince of naval writers, Captain Mahan, that I am not going to take up your time by spealsing on that part of the question. If on the other hand, when the great question of the effect of sea power is before us, 1 speak about one comparatively small detail, I hope it will not be thought too trivial to be of interest. When Carthage enjoyed supremacy at sea we read that she had amongst her fleet hundreds of triremes and also vessels with five banks of oars; now the lecturer tells us that Rome went one better than that, and had not only five-bank galley's, but war galleys with six banks of oars. It has often been a puzzle to me how they could work these oars. If you consider a trireme, which means a vessel with three banks of oars one above the other, it is dificult to understand liow the oars were worked, but when it comes to five banks it seems impossible. The upper bank of oars would be so long and heavy as to be almost unmanageable, whilst the lower tier of oars would be so close to the water that I cannot understand how they could be used except in a dead calm. Can the lecturer tell us if there are any authentic drawings or models of these vessels? I have not been able to find any. I know they are alluded to by historians and poets, but only in a cursory way. Naturally, the writers of those days would not go into technical details as to how these banks of oars were managed, but it would be very interesting to us sailors if we could know something about them. They are represented in sculpture, but are too grotesque to be reliable, besides being out of proportion. I do not mean to imply that they never existed. When we consider the wonders of Egypt, and remember how those ancient people transported those hugh obelisks to Alexandria from their quarries hundreds of

Vol. XIIII. 
miles distant, we can believe almost anything. A thousand years hence people will wonder how we managed to get about the world in two and three-deckers propelled, up to a recent date, by sails only; but they will only have to come to our museums, or to visit Greenwich, or South Kensington, and sec for themselves models of the vessels which were actually used. I had the pleasure in 1854 and 1855 of serving in a three-decker with my excellent friend the Chairman. I think I can say also she was the first steam three-decker fitted with a screw and engines. I allude to the "Royal George," which was fitted with engines of only 400-H.P., and consequently could make little or no progress against a head wind. I have only now to thank the lecturer on behalf of the Institution for his intercsting paper. We are very much obliged to him, and also to Professor Laughton for presiding.

MajorJ.W.H. M.IRsmall-W'Est (th Bu. Somersetshire Light Infantry):-I hesitate somewhat to rise in this theatre after the distinguished naval officers who have preceded me, but I would like as a soldier to thank the lecturer for the most thoughtful and searching paper which he has read to us, and I say "thoughtful " in the sense of provoking thought. There is almost a fault in it, however, and that is that there is so much contained in it for one short hour, that it needs to be taken away and thought over. I wish to thank the lecturer, then as a soldier, for giving us so much to think about as to the value of sea power. I have heard the word "military" used this afternoon in its restricted sense, but I venture to suggest that "military" does really include both the sea forces and the land forces. I think one of the clief points shown in this paper is, as Admiral Colomb so clearly told us, the importance of kecping the road, that is, the sea open, for the passage of armies by means of the fleet. To this country of ours the fleet is our first line, and this scarcely requires now to be emphasised. The nation as a whole is beginning to realise that fact, and appreciates what the fleet means to us; but $I$ think in these days it is sometines a little forgotten how important is the othet military branch, and that we still want soldiers to go to the other end of the street, and to be able to land when and where required. There is only one way of fighting, and that is by offensive action, even in the case of self-defence, and for the sake of right and justice. It is offensive action which wins the battle, and which wins the canpiagn in the end, and therefore we must have an Army fit to go anywhere. Let it be small by all means. We do not want vast numbers, but we do want a little ready force to move about the world. This struck me particularly cven in the Civil War that we heard alluded to between Pompey and Casar. When one looks at the Mediterranean and remembers that that merely civil contest between two parties in Rome was fought all over the shores of the Mediterranean it brings home the importance of kecping our land forces as well as our sea forces in proper trim. One other point struck me in listening to the summary of the Punic Wars, which I think may be of interest. When the Mamertines first appealed to Rome for assistance as against the Carthaginians, Rome had no fleet whatever, it is true, and therefore found a difficulty in getting troops across to Messina on the other side of the straits; but. there was another reason why the Roman Senate hesitated to assist these Mamertines, and indeed refused their. request. The affair was by no means creditable to the latter. Being kindly received by the people of Messina, they rose in the night, slaughtered all the male inhabitants, married their widows, and settled down as rulers of the town. The Roman garrison of a Greck town on the other side of the straits, Rhegium, if I remember rightly, thought this was a very excellent precedent, and proceeded to imitate the Mamertines by similarly dealing with the town and inhabitants of Rhegium. The Romans in consequence sent a force to suppress these Rhegium soldiers. It would, therefore, have been highly inconsistent on their part to send a force to assist the Namertines; but allhough the Senate refused this assistance, the people of Rome-with whom lay the power 
to decide on peace or war-cridently began to value the importance of extraItalian possessions, as the lecturer called them, and they seized on this pretext for war, evidently for the sake of trying conclusions with the Carthaginians, and if possible, obtaining possession of Sicily. When it came to manning the fleet, Duilius had to get men pretty well straight from the plough, and trained them to row these triremes, or whatever ships they were, seated on banks by the side of the sca, whilst the ships were being built. I was also most interested to hear the question as to these banks of oars, because the same difficulty occurred to me. I had the curiosity to make out a rough draking to see what the length of these oars would be likely to be; and I fail to see, according to my calculations, how any mortal man, such as we know nowadays, could possibly row in the fifth row, let alone the sixth or scventh row. I hope, therefore, to liear from the lecturer whether he can give us any reliable information on the subject.

The Cumrmas (Professor J. K. Laughton) :-It remains for me, gentlemen, to ask you to pass a vote of thanks to the lecturer. Before doing so, I should like to add my little quola to the discussion, perhaps in the way of a question. I think, too, I can answer the question put by Sir Nathaniel Bowden-Smith, and referred to by Major Marshall-West, as to the oars of the ancients. I can say positively that there are no trustworthy models of the galleys of ancient times, and certainly no pictures. There are, indeed, the grotesque sculptures on Trojan's Column, of which I fancy Sir Nathaniel Bowden-Smith was thinking. I should say they have less resemblance to the war galleys than even the pictures in the Bayeaux tapestry have to sea-going ships. But how the different banks of oars were arranged is, and for the last 1200 years has been, an insoluble problem. We must remember that this problem is not how the oars could be arranged, but how they actually were arranged, and for that there is no satisfactory cridence. Major Marshall-West puts it that the length of the oars in the fifth bank would be excessive; but how would it be for those of the tenth bank? and ships of ten banks of oars were not uncommon in the Syrian war; they wero perhaps equivalent to the three-deckers of a hundred years ago. But more than this, it is on record that a ship of forty banks of oars was built. I don't know that she ever got to sea, but if the oars of the fifth bank were too long for human arms what would be the oars of the fortieth bank? It is beyond conception. In mediaval times, when galleys were still the typical ships of war in the Mediterranean, they were propelled by oars, two or, in later centuries, three on a bench; and these galleys were written of as biremes and triremes. As men got more ambitious and put four, five, six and seven oars to a bench they found, after a little experience, that whilst three men on a bench could pull three separate oars with advantage, when they got beyond three it was more economical of labour to have one large oar, a sweep in fact, and so they adopted large oars pulled by four, five, six, or seven men. These came into use about the year 1400 , and from that time onwards galleys had large oars. Writing about the year 1600, Pantero Pantera say's he had heard that their ancestors had galleys where each man pulled a separate oar, but for himself he could not understand how it was possible. He had the same difficulty about oars that had gone nut of use only about 150 years before his time, that we have now about the oars of ancient times. Fortunately, models of the mediaval galley's have been preserved at Venice. . Some of these were exhibited a few years ago in the Italian Exhibition at South Kensington. They had previously been very carefully described by Sir Henry Yule in the introduction to his "Marco Polo." There is one point about the Carthaginians that has often occurred to me, which $I$ will mention. The Carthaginians were unquestionably experienced sailors, but it seems to me that they lad little or no knowledge of naval tactics; they made some very remarkable royages, but they had not, and could not have had any experience in naval war. No doubt they had pirates to control, but this did not call for any knowledge of fleet mancuvres. That seems the natural suggestion, from the circumstances, but the proof of it is that they were utterly unable to out 
manourre the Romans, who were admittedly very ignorant. On every occasion they allowed the Romans with their swinging brows or gang-boards to make easy victims of them. I have sometimes wondered what the old Athenians, with their skilled tacticians--Phormio, for instance-would have done against such things. I fancy they would have rowed round them and sunk them-galley and brow together-without much difficulty. I may mention that gang-boards of a similar kind were fitted on board the Russian slips by l'eter the Great, and that still later they were fitted on board the ships of the French fleet, which fought the indecisive action with Mathews off Toulon, in 1744. In neither case, however, were they of any use. Many of you will of course know that in the wars of Queen Anne's time, the favourite French tacties were to lay the English ships aboard when they could, and overpower them by the great crowd of men they could throw on board. M. de Court had no doubt the same idea in 1744 , but in he skirmish-it was little more-that took place, he had no opportunity of using them. There is one other point-this is a question which I should like to ask. After the battle of Ecnomus, fought off the modern Cape Bianco, in Sicily-perhaps in point of numbers the greatest battle that has ever been fought at sea-the defeated Carthaginians drew back and took up a position off Carthage. The Romans then sent over an army of invasion. They learned that the Carthaginians were lying in force off Carthage, and so did not go there but landed at the east of Cape Bon, in the bay then called Clupea and now Kallibia. The Carthaginian fleet, still very formidable in point of numbers, was not more than 10 or 12 miles distant. Apparently it was a fleet in being. W'hy did it not linder the invasion? It was certainly numerically strong enough to do so. The only explanation that occurs to me was that they were so thoroughly cowed by the defeat they had received off Cape Bianco that they were not effectively "a fleet in being"; but possibly the point has occurred to the lecturer, and he may be able to explain it more in detail. There is one thing which I must protest against, as being in a measure personally interested in it. On the last page the lecturer compares the battle of Actium with the defeat of the Spanish Armada. He says the elements played a large part in the contest. That I beg most explicity to deny. The elements had no part whatever in the defeat of the Spaniards. Then lie speaks of the Spanish vessels towering abore their pigmy assailants, and the victors sailing in light, almost piratical craft. I think I have shown in various places that the victors did not sail in light piratical craft, but that the ships of the English "Navy Royat," which were the principal instruments in that great victory were, practically speaking, as large as the Spanish ships, and were much more heavily armed. However, that is a point almost foreign to the subject of the lecture, and $\bar{I}$ do not now insist upon it. I will conclude by asking you to return a very hearty vote of thanks to the lecturer for the most interesting discourse which he has given us.

Mr. Marsinal, in reply, said :-1 should like just to make a few remarks on the questions which have been put; and in the first place I am rather glad that the only serious objection, as I regard it, has been the last which is an objection to what I may call an illustration from a large subject, about which I candidly admit I know nothing at all, and not an objection to anything concerning the subject of the lecture itself. With regard to the landing of the Romans in Africa, I think Professor Laughton has lit exactly the right reason. The fact wits that this army" of invasion was on board the fleet which beat the Carthaginians off Ecnomus, and which went straight on to the African coast; and the probability is that the Carthaginian flect had not had time to recover itself suficiently to make any successful resistance or any resistance at all. In regard to the comparison between the Romans as being Jandsmen and the Carthaginians as being expert sailors, I entirely agree with what Professor Laughton says; and when I spoke of the skilful manceures of the Carthaginians, I am afraid that my meaning was not very clear. W'hat I meant was practical manourres-that is, such manouvres in the management of their slips as able merchant sailors would be acquainted with 
rather than naval mancuves. Now we come to another question, and upon that point I am extremely obliged to Professor Laughton for answering it for me, or rather for admitting that there is no answer. If $I$, as an old oar myself, whose favourite form of athletics at Oxford and elsewhere was rowing, had been able to discover by any means how even five banks of oars were worked, I should have considered it from my point of view the most interesting part of the whole lecture. I have been utterly unable to discover it, but from. the references in numerous histories, and also from references in such out-of-the-way places as the Comedies of Aristoplianes, I cannot but believe that at least five banks of oars were worked in some way or other; and I read, as Professor Laughton says, of forty banks of oars. When I come to that $-I$ do not believe it. Nothing remains for me to do but to thank you all very much, both those who have spioken for their kind expressions, and all the audience for the very great assistance which they have given me, in going through a large amount of matter in a short time, by their kind attention. 